\title{
"CABOCLO É TUDO": ALIANÇA COMO CORRENTE"
}

\author{
Márcia Nóbregaª
}

Resumo: Este artigo dedica-se a pensar a relação que alguns habitantes da Ilha do Massangano, uma ilha situada no trecho submédio do rio São Francisco, estabelecem com entidades por eles chamadas de "caboclos". O que argumento é que, por viverem em uma terra no meio de águas, organizam sua relação com tais entidades a partir de uma composiçáo com as correntezas que os cercam. A correnteza das águas dá força às correntes de caboclos, como eles as nomeiam. Nesse sentido, para fazer a vida perseverar, mobilizam regimes de aliança, ao modo de uma corrente, com os caboclos, a terra, a água.

Palavras-chave: Caboclos; Corrente; Rio São Francisco; Aliança.

“CABOCLO IS EVERYTHING”: THE ALLIANCE AS STREAM

Abstract: This article is dedicated to think about the relationship that some inhabitants of Massangano Island, an island located in the submiddle section of the São Francisco River, establish with entities they call "caboclos". What I argue is that, because they live on land in the middle of water, they organize their relations with such entities based on a composition with the streams that surround them. The streams of the waters gives strength to the caboclos's streams, as they name them. In this sense, to make life persevere, they mobilize alliance regimes, like a stream, with the caboclos, the land, the water.

Keywords: Caboclos; Stream; São Francisco River; Alliance.

Sei que agora é tarde, e temo abreviar com a vida, nos rasos do mundo. Mas, então, ao menos, que, no artigo da morte, peguem em mim, e me depositem também numa

\footnotetext{
${ }^{1}$ Como citar: NÓBREGA, Márcia. "Caboclo é tudo": aliança como corrente. Debates do NER, Porto Alegre, v. 2, n. 38, p. 181 - 210, 2020.

${ }^{2}$ Doutora em Antropologia Social pela Universidade Estadual de Campinas, Brasil. E-mail: marciamnobrega@gmail.com.
} 
canoinha de nada, nessa água que não para, de longas beiras: e, eu, rio abaixo, rio a fora, rio a dentro - o rio. João Guimarães Rosa (1994, p.413) A Terceira Margem do Rio

"Caboclo é tudo" ou "tudo é caboclo" é como meus interlocutores da Ilha do Massangano costumavam responder às minhas perguntas sobre o que, afinal, são os caboclos. Caboclo é um tipo de alma? É um encantado? Um orixá? Um guia? Caboclo é boiadeiro, sereia, marujo, cosminhos, Santa Bárbara? Caboclo é um índio? Ou ainda, seriam eles próprios também caboclos? "É e não é", impacientavam-se. "Se baixa numa gira é porque é caboclo", uma delas me resumiu com a clareza que minhas perguntas jamais haviam sido capazes de formular. ${ }^{3}$

Conforme procurarei demonstrar, a afirmação de que "caboclo é tudo" e "tudo é caboclo" decorre, em parte, do fato de que ele é pensado como estando potencialmente em qualquer lugar, no vai e vem sobre as águas, de seu vínculo com a terra. Qualquer sobrevoo pela literatura acadêmica sobre o tema (Cf. Santos, 1995) nos fará pousar sobre a assertiva de que “caboclo é o dono da terra". Mas que terra exatamente é esta de que se está falando, quando aportamos sobre a Ilha do Massangano? A precisão dessas formulações, do fato de os caboclos serem tudo em seu vínculo com uma terra em águas, será o guia e o norte deste artigo. A nossa rosa dos ventos.

A Ilha do Massangano é uma porção de terra rodeada pelas águas do rio São Francisco ${ }^{4}$, onde vive uma população rural negra de cerca de 180

${ }^{3}$ Este artigo é um desdobramento de um capítulo de minha tese de doutorado, defendida em 2019. Para o doutorado, realizei pesquisa de campo entre os anos de 2015 e 2018. Contabilizando o tempo do mestrado, também realizado junto a esta comunidade, somam-se cerca de dez anos de trabalho de campo entre idas e vindas.

${ }^{4} \mathrm{O}$ único grande rio exclusivamente brasileiro que tem em uma contagem possível, das nascentes à foz, 3.161 quilômetros de comprimento, e ocupando o lugar do terceiro maior rio em extensão do país. O rio São Francisco conta com 36 afluentes e está dividido em quatro regióes fisiográficas, sendo elas, 1) o alto São Francisco, das nascentes até as 
famílias que conformam, como eles gostam de dizer, "um povo só”. Situada na porção submédia do trecho de rio que corta o sertão nordestino, a Ilha está a um só tempo entre o seco semiárido da caatinga e as águas do rio; entre as cidades de Petrolina e Juazeiro, habitando a divisa entre os estados de Pernambuco e da Bahia, respectivamente. A Ilha está no coração do que foi o entroncamento das rotas mais movimentadas do comércio do início do século XX na região, cujo trecho navegável do rio conformava a "carreira grande" ${ }^{5}$ que ia de Juazeiro, na Bahia, até Januária ou Pirapora, em Minas Gerais, de modo a unir o Sudeste ao Nordeste brasileiro - motivo pelo qual passou a ser chamado de "o rio da Integração Nacional" (Neves, 1998). Isso pelo menos até a construção da Barragem de Sobradinho, há cerca de $40 \mathrm{~km}$ a montante da ilha, pela Companhia Hidrelétrica do São Francisco, a CHESF. O sistema de barragens construído entre as décadas de 1950 e 1970 ao mesmo tempo que pôs fim às carreiras, freou as correntezas das águas, modificando a mecânica de suas terras. Ao longo de cerca de dez anos de pesquisa junto a eles, ouvi histórias de um tempo em que não apenas pessoas e embarcaçóes caminhavam sobre as águas, mas também a própria terra andava, arrastada pelas correntezas. A título de prova sugeriam que bastava observar o desenho das beiras ao nosso redor: "encaixa direitinho uma na outra”.

Para dizer como eles, enquanto o rio tinha "corrente" a relação posta entre terra e rio os fez viver uma geografia bastante modulável. Uma interlocutora que há tempos mora "na rua", isto é, em Juazeiro, ao me contar

corredeiras de Pirapora, em Minas Gerais; 2) o médio São Francisco, que segue até a cidade de Remanso na Bahia; 3) o submédio São Francisco, compreendendo o trecho até as cachoeiras de Paulo Afonso, que hoje estáo embarreiradas; e, por fim, 4) o baixo São Francisco, que corresponde ao que daí corre até a sua foz, desaguando no estado de Alagoas. O rio margeia ao todo cinco estados: Minas Gerais, Bahia, Pernambuco, Alagoas e Sergipe (Ferraz \& Ferraz Barbosa, 2015).

5 As viagens duravam de um a dois meses - quando faziam a "meia carreira", que ia de Juazeiro até Santa Maria da Vitória, na Bahia - ou de três a cinco meses - quando era feita a "carreira grande" que ligava Juazeiro à Pirapora em Minas Gerais (Neves, 1998).

Debates do NER, Porto Alegre, ano 20, N. 38, P. i 8 I-2 io, Ago./Dez. 2020 
de suas saudades da Ilha, deu-me a mais bela definição do que seja viver ali, "lá, onde se morre afogada na areia". O aparente paradoxo de sua fala revela a mecânica das movimentaçóes dos caminhos e do que gera a vida na Ilha. Por viverem na beira, são beiradeiros: categoria, muitas vezes de acusação, que lhes atribui uma "ciência das beiras" (Martins Costa, 2013), em contraste com o conhecimento versado sobre o labirinto da mata cinzenta da caatinga, este que é próprio ao domínio dos vaqueiros ou dos mateiros, nos dizeres locais. Náo é raro que os habitantes da Ilha do Massangano, acostumados a viver numa terra que afunda, muda de contorno e de lugar, olhem para a terra que é dita "firme", a que conforma suas porçóes continentais vizinhas, como um mundo que se faz em oposição ao seu. No entanto, a imagem de oposiçáo entre terra e água não coincide com a de uma contraposição - no sentido em que um é contra o outro. A dupla condiçáo com a qual se acostumaram a viver, de estarem a um só tempo situados no meio do sertâo do seco semiárido nordestino e no meio das águas do rio São Francisco, os faz produzirem para si uma vida cujo motor é acionado por uma engrenagem que se dá pelo efeito de composição entre terra-água. A esta composição dá-se o nome de correnteza ou, no dizer local, de "corrente" - peça relacional fundamental de sua relaçấo com os caboclos, seu guia, seu caminho, eixo de perspectiva, sentido e direção.

É a partir da imagem de corrente que organizam sua relação com os caboclos. Por exemplo, de um conjunto total de 27 correntes de caboclo (que nunca me precisaram exatamente quais sejam), destacam a proeminência de duas delas: a "corrente das águas" e a "corrente dos índios" (ou "das matas"), versadas nos labirintos das caatingas. Nesse sentido, uma das direçôes deste artigo consiste em observar o que acontece à corrente dos caboclos quando a correnteza das águas é frenada pela construção do empreendimento barrageiro pela CHESF. Situados entre duas das barragens, a de Sobradinho e a de Itaparica, os habitantes da Ilha do Massangano apontavam que sua terra já náo se movimenta como antes e que agora ela cresce, de baixo para cima, assoreando o leito do rio que, me disseram, "raseou". 
Ao contrário da vertigem proporcionada pelo que alguns teóricos alinhados ao marco do Antropoceno chamam de "era das catástrofes" (Stengers, 2015), quando a mudança da natureza é tâo rápida que ultrapassa em velocidade nossa capacidade (da cultura) em compreendê-la, tal disjunçáo catastrófica, o "fim do mundo", me foi apresentado de modo peculiar pelos que habitam os ciclos do rio: $\mathrm{o}$ assombro não me foi descrito em termos da velocidade de sua mudança, mas no fim de sua capacidade de variaçáo. A inconstância de sua terra modulável é, com as barragens, estabilizada em partes destacáveis: de um lado, a terra que cresce; de outro, a água que mingua. Assim, não é que a natureza ou a terra estejam mudando rápido demais, e sim o oposto: um rio parado e sem correnteza produz uma terra que não mais anda, mas cresce, sob ameaça de conectar-se definitivamente à terra-firme e doravante da caatinga - de deixar, por fim, de ser ilha.

Para pensar a correlaçáo entre tais modos de correnteza e de paragem, que informam as relaçôes dos habitantes da Ilha do Massangano com seus caboclos, convido o leitor para uma caminhada junto aos que ali permanecem. Assim espero alcançar os sentidos do que sấo os caboclos e em que medida eles podem ser tudo. A seta dos caboclos, a nossa rosa dos ventos, aponta para o cháo: a terra, a água e o ao redor.

\section{ENTRE A CORRENTE E A CORRENTEZA: CABOCLO COMO FORÇA}

Diz-se na Ilha do Massangano que ali, com os caboclos, só se trabalha para o bem, sem dinheiro, e com Deus na frente. Aqueles que "andam mais os caboclos", se questionados se são da Umbanda, darão de ombros e dirão que são, no máximo, espíritas - no sentido de que lidam com espíritos e não exatamente por aderirem ao espiritismo kardecista. As casas de caboclo da Ilha do Massangano são chamadas de "Mesa Branca", onde trabalham com distintas modulaçóes espirituais: primeiro os espíritos de cura (os "guias", que em geral são espíritos de médicos e índios sabidos dessas ciências) que 
vêm tratar o consulente, devidamente deitado sobre uma mesa coberta em panos brancos; somente depois, quando passam ao "salão", é que vêm os caboclos com quem brincam e "pisam no ouro", fazendo com eles suas giras. $\mathrm{O}$ pouco rendimento de minhas perguntas para que definissem o tipo de orientação religiosa que professavam na lida com os caboclos, contrasta com o ânimo com que se descrevem como católicos. Sua ideia de religiáo acompanha a de "lei": assim como há a "lei de católicos", há também a "lei de crente". Sua lida com os caboclos, no entanto, nunca me foi descrita nesses termos. Ao contrário, o que se escuta é que caboclo não tem nação, não tem pátria, não tem lei.

Dizer que caboclo não tem lei é dizer que sua relação é com a terra, sendo livre para viver no "por aî", onde bem quiser. "Ir para os caboclos", "caminhar mais os caboclos", "brincar com os caboclos", "pisar no ouro", "ir para o pisa-pisa” são os modos como se referem não propriamente a uma religião, mas às práticas de cuidado entre os seres com os quais caminham. Ainda, mais do que cuidarem deles, o que esperam em suas idas "aos caboclos" é que sejam cuidados por eles. Porque "caboclo mesmo se cuida sozinho", é o que costuma dizer Peba, uma "caboqueira" ou "média” fina, que é como na Ilha se referem àqueles que costumam andar com os caboclos. Sendo os caboclos "espíritos de luz" e que "têm força”, os que estão em sua companhia mais querem é ficar fortes como e com eles.

E, por viverem em uma ilha, arrodeados pelas correntezas das águas, convivem com uma alta densidade de caboclos. Caboclos que estâo no "por aî" e que se precipitam nas giras conforme seja a corrente da vez, de modo não concomitante, sempre um e depois o outro. Se é "fino", não há limites para a quantidade de caboclos que um caboqueiro pode pegar. "Tem os caboclos chefes, mas também tem os agregados", brincou uma delas, explicando que "chefe" é aquele que ocupa a "gerência" da cabeça do caboqueiro, sendo a sua "coroa": São José era o guia de Berto Barrinha; Vencedor, o de Peba. Ambos foram/são os "enfrentantes" ou "chefes" de suas respectivas casas, que têm como "agregados" os demais caboclos. Ainda, se nem toda caboqueira seja "fina", tampouco nem toda "caboqueira fina" quer ser coroada. Temem 
que lhe troquem um espírito seu "de luz" por outro "perturbado". Coroar a cabeça difere de "raspar a cabeça", de "matular", como é dito no canzuá, como ali chamam as casas de Candomblé onde se "bate couro". "Coroar", na Ilha do Massangano, consiste num rito em que se produz, com algum tecido branco, uma espécie de "coroa", "flor", ou "bonequinho", que, ao ser posto junto a uma cruz e uma imagem de seu santo correspondente em cima da cabeça da "média", "coroa" a relaçâo de determinada caboqueira com seus caboclos. Depois disso, a caboqueira recém coroada deve andar com tal coroa anexada à roupa do corpo, e um broche, por cerca de um ano. Ensinam que é assim, andando juntos, que caboclo e caboqueiro ganham mais força.

Nas casas de caboclo da Ilha não há uma fórmula geral que dite a ordem em que os caboclos apareceráo nas giras. O que sabem é que os trabalhos sempre começam com a corrente do "caboclo chefe" do dono da casa e terminam com os "cosminhos", que é como chamam as entidades associadas às crianças e aos gêmeos Cosme e Damião. "Aqui começa com o Rei Sultáo", diz Peba. "Depois disso não tem uma ordem: é um depois o outro, conforme se vai tirando as cantigas", me disse outra caboqueira de lá. Cada caboclo tem uma cantiga, e lembrar de um caboclo, fazê-lo vir à terra, é lembrar de sua cantiga - um náo pode vir sem a outra. A depender do caboqueiro que esteja presente, de sua predileção e memória para cantigas, varia-se a ordem e a composição dos caboclos de uma gira. Rei Sultáo, Ogum Beira Mar, Santa Bárbara, Juremeira, Oxóssi, Preto Velho, Boiadeiro, Janaína, Marujo, Cosminhos - não necessariamente nessa mesma ordem -, são alguns dos caboclos que "baixam" por ali.

Há no Jarê um tipo de candomblé de caboclo presente no alto sertão do São Francisco, Chapada Diamantina, uma disposição de caráter menos aleatório entre o caboclo que abre e o que fecha a gira, e o que é apresentado na Ilha. Segundo a etnografia de Gabriel Banaggia (2015), no Jarê, são os domínios onde tais entidades habitam que ditam a ordem de chegada nas giras: primeiro são as águas (sereia, mãe d'água, Janaína), depois as matas (que tem na frente também o Rei Sultáo), em seguida os espíritos de luz (no 
Jarê identificados como Vaqueiro, na Ilha como Boiadeiro), então vem o povo velho, e, finalmente, os Cosme e Damiáo (p. 263). Na Ilha do Massangano, se por um lado afirmam que o caboclo coroado pelo dono da casa é aquele que abre a gira, por outro, nunca me disseram que os cosminhos a "fecham". Insistem que quem fecha os trabalhos é aquele que os abre: é uma atribuição do caboclo chefe da casa. O que ocorre, eles enfatizam, é que os cosminhos são "sempre os últimos". Entidades associadas em algumas casas de matriz africana aos Erês e aos Ibejis (Serra, 1978), ainda que estas entidades estejam ausentes no repertório das casas de Mesa Branca da Ilha, pode-se dizer que o encerramento das giras na companhia dos cosminhos deve-se menos à qualidade gemelar dos Ibejis (orixá que rege os gêmeos) do que ao aspecto infantil dos Erês: a dispersão provocada por eles indica o momento de retorno para casa. O que me disseram é que os cosminhos são "meninos" e que são sempre "dois-mais-um": Cosme, Damião e depois Doú. Por serem crianças, estão sempre "correndo caminho", vadiando "por aî", e, por serem gêmeos, podem habitar mais de um mundo, de modo simultâneo, lado a lado, precipitando-se, por vezes, sobre uma mesma terra.

Com exceção da Quaresma, que é o "tempo das almas", o tempo dos caboclos na Ilha é todo dia. E há uma profusão deles. Nos tempos em que o "rio tinha corrente", isto é, antes da construção do complexo de barragens pela CHESF, houve na Ilha cerca de quatro casas de caboclo. $\mathrm{Na}$ Ilha do Massangano, diz-se casa, salão de caboclos, mas nunca "terreiro", como é comum para o candomblé. Lá terreiro designa o espaço anterior à casa, o pedaço de chão em frente à sua porta dianteira. Nesse sentido, cada casa da Ilha tem o seu terreiro - até mesmo as casas de caboclo. Dessas casas apenas uma resistiu à estiagem do tempo e do rio: a casa de Peba que se fez como desdobramento da casa e das obrigaçóes de seu pai. ${ }^{6}$ Duas outras,

${ }^{6}$ Um levantamento feito em documento chamado Cartografia Social dos Terreiros de Candomblé e Umbanda de Juazeiro e Petrolina (Marques \& Novais, 2015) relata que a Associação Espírita e de Cultos Afro-brasileiro, fundada em 17 de dezembro de 2007, estimou que entre as duas cidades há cerca de 400 terreiros, considerando o que chamou

Debates do NER, Porto Alegre, ano 20, N. 38, P. I 8 I-2 io, Ago./Dez. 2020 
pertencentes a dois irmãos, Berto Barrinha e Maria de Lauro, foram as responsáveis por coroar muitas das caboqueiras finas que a Ilha conheceu. Enquanto a de Maria de Lauro destacava-se nos cuidados de cura de sessão de mesa, a de Berto Barrinha, chamada "casona", tornou-se famosa pelas grandes festas que produzia, pela força de suas giras, pela capacidade de chamar caboclos e fazer a todos se encaboclarem.

de "Candomblé, Umbanda, tendas, casas brancas, casas de sessão, centros espíritas de orientação umbandista, mesas brancas, casas de orações, entre outras" (p. 19). Tal mapeamento considerou que a Ilha do Massangano conta com apenas uma casa-terreiro: aquela mantida por Chagas, "chegante" na ilha, que abriga os assentamentos do antigo terreiro de Pai Walter, de quem é Ogã. Dessa forma, tanto a casa de Peba quanto a de Silvano se viram como inexistentes, fora do mapa. Inspirada pelos "mapas mnemônicos de socialidade" (Marques, 2013), ofereço aqui um breve contramapeamento destas casas de caboclo da Ilha do Massangano, traçadas pelos dizeres, práticas e memórias de quem muito caminha ou caminhou junto aos caboclos de lá.

Debates do NER, Porto Alegre, ano 20, N. 38, P. i 8 I-2 io, Ago./Dez. 2020 
Fotografia 1 - Cosme e Damião e Peba, em sua casa de caboclos (Márcia Nóbrega, 2015)

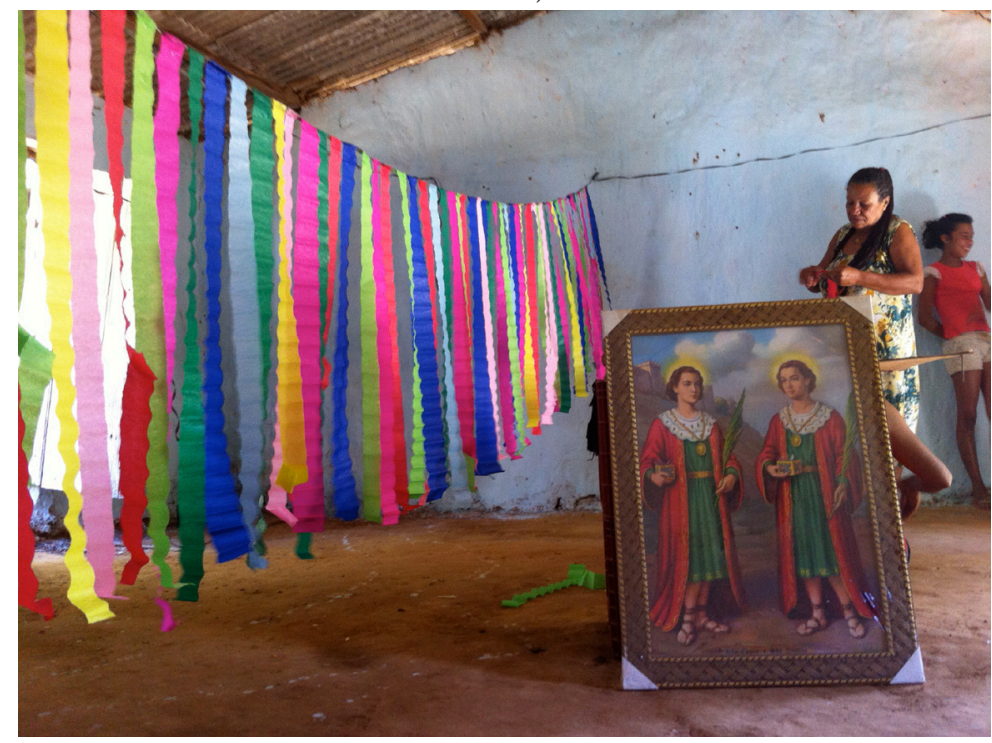

A casa de Berto Barrinha é a que lembram com mais saudades. Silvano, um de meus interlocutores que também já teve uma casa de caboclos na Ilha, me contava de como brotava água de suas mãos e de seus pés ao adentrar no espaço interior da casona - "ali tinha força!", disseram-me ele e tantas outras pessoas que giraram as giras dos caboclos de lá. Isso porque, Silvano me explicou, a casa de Seu Berto "trabalhava na corrente das águas". Tudo se passa como se as águas dali movessem não apenas a terra de um lado para outro, mas também algumas qualidades de seres que nela habitam: seja sua gente, sejam certos caboclos que retiram das correntezas a força de sua corrente. Com alguma facilidade, deparava-se com navios repletos de pequenos marujos, os "nego d'água"; mas também com algumas sereias que, metade gente metade peixe, estacionavam por cima das pedras onde corriam cachoeiras. Os caboclos de modo geral, e aqueles da "corrente das águas" de modo particular, me foram descritos na Ilha do Massangano como seres mais afeitos às águas. 
A "corrente das águas" pertence à "Linha Branca" e se opóe ao "Esquerdo". Se falam de apenas duas linhas (a Branca e a Esquerda), Peba e Silvano afirmam que são 27 as correntes de caboclos que atravessam a Ilha. Falam de corrente das águas, dos índios, mas também dos Marujos, de Oxumaré, Boiadeiro, Cabocla Índia, Sultão das Matas, Preto Velho, Juremeira, Sereia, Janaína, Martim Pescador, Ogum Beira Mar, Santa Bárbara, Oxóssi etc., variando sempre a ordem de enunciação e nunca completando a lista à exaustáo. O que importa, disse Silvano, é que há 27 correntes que correspondem às 27 "qualidades de caboclos". No entanto, ainda que sejam todas da "Linha Branca", se reúnem em dois grandes subconjuntos de correntes: a "corrente das águas" e a "corrente das matas" (ou "dos índios"). Isto é, se por um lado falam da corrente das sereias, do Rei Marinho, Marujo, Martim Pescador, e, por outro lado, da corrente dos Boiadeiros, Sultáo das Matas, Juremeira, Oxóssi, todas são igualmente ditas, respectivamente, por "corrente das águas" e "corrente das matas". Cada caboclo é, em si, uma corrente, porque ele é um e vários ao mesmo tempo - e por isso pode povoar o "por aî" dos mundos da terra da Ilha. Nesse sentido, sendo caboclo uma "corrente" ou "uma força", diz-se também que tais entidades não têm ou não respeitam lado, inclusive no que diz respeito à divisáo mais fundamental para meus amigos, entre as linhas Branca e a da Esquerda.

Peba, que insiste que não trabalha com "o Esquerdo", não esconde que um de seus três guias de frente é dessa linha. Enquanto Vencedor, seu caboclo regente de nascença, e a Caboclinha Coroada do Rio são da "linha branca", o Caboclo Gritador é da "linha esquerda". "Ele só chega gritando", sorriu Peba. No entanto, ela esclareceu, Vencedor o orientou que para andar "mais eles" na Ilha é preciso aprender a se comportar: "não pode andar xingando, é só rezando!". Completou dizendo que ainda que baixe como da linha esquerda, "aqui, na minha casa, ele vem como linha branca". Isto é, ainda que Gritador seja da Linha Esquerda, ele não deixa de ser da corrente dos índios e, para vir à sua casa, deve agir como se fosse da Linha Branca. O que Peba me dizia é que toda relação entre lados só é apreensível se a corrente entre eles "passa", "tem força" e "dá bem". Falar de corrente é referir-se a uma 
forma de agenciamento entre seres, uma modulação que os liga à substância do local onde habitam: às águas ou aos segredos da mata da caatinga.

Silvano hesitou quando lhe perguntei se havia uma correspondência entre a existência abundante de caboclos da corrente das águas que descem em suas giras e o fato de viverem em um meio de rio. Sopesou que em suas andanças por casas de caboclos em outras margens do rio, já viu muitos caboclos da corrente das águas baixarem na caatinga assim como muitos caboclos da corrente das matas precipitarem-se pelas terras de beiras d'água. Mas concluiu que na Ilha é diferente. Foi sem ressalvas que traçou uma correlação entre a força das águas e a boa qualidade dos caboclos de lá. Lembrou-se com entusiasmo do tempo em que se fazia a festa da Marujada de Berto Barrinha, quando, um após o outro e em efeito cascata, os médiuns se "encaboclavam" sobre os barcos que saíam em cortejo ao redor da Ilha. Ali, sobre a força da correnteza, a corrente das águas ganhava tanta força, que quem se aventurasse a segui-la tinha que cuidar para náo cair rio abaixo. E de fato não caíam. Como insiste em dizer Dona Amélia, cunhada de Berto Barrinha: ali a corrente é forte. Tal força, me explicou, deve-se ao fato de que vivem "no meio do rio", onde a correnteza passa em toda a sua potência. Com frequência, traçam uma correspondência entre o que seja a corrente das águas, da linha dos caboclos, e o que seja a correnteza das águas que circunda a Ilha, de modo que muitas vezes corrente e correnteza aparecem em suas falas com significados próximos. Ambos falam de força: a das águas e a de onde os caboclos retiram a possibilidade de existirem na Ilha em sua potência.

\section{O GIRO E A GIRA: CABOCLO COMO CAMINHO}

O tempo das caboqueiras finas e coroadas da casona de Berto Barrinha é lembrado como um tempo em que caboclos e "médias" iam às giras não apenas por um desejo de fortalecerem-se, curarem-se, mas também para "pisar no ouro" e brincar com os caboclos - nem que fossem os caboclos dos 
outros. Em certa medida, é como se caboclos fizessem tão parte da comunidade quanto as caboqueiras, muito embora nunca tenham apresentado um ao outro como parentes. No entanto, se não são parentes, tratam-se como se fossem. Pai Walter - um pai de santo do Candomblé que, ainda que não seja da Ilha, há anos caminha por ali - certa vez disse que "caboclo não tem pai e nem mãe”. Meus interlocutores da Ilha do Massangano diriam que, se não tem pai nem mãe, tem padrinho e madrinha. Foi para encontrar Cormira, o cosminho de Corina, outra caboqueira fina de lá, que Dona Amélia certa noite atravessou a Ilha de ponta a ponta para ir "brincar caboclo" em uma gira na então casa de Silvano. Queria saber a opinião de Cormira, que há tempos conhece, sobre o que fazer com suas vistas, que, de tão anuviadas, lhe permitem enxergar cada vez menos. "O jeito, minha madrinha, é se conformar", disse a cosminho. Apesar de conhecer Cormira há décadas, Dona Amélia quase nada sabe sobre a vida da cosminho de sua prima Corina. $\mathrm{Na}$ verdade, o que lhes interessam nesse vínculo é saber o que os caboclos sabem deles: o que Dona Amélia queria saber de Cormira era o que Cormira sabia sobre Dona Amélia.

O tom evasivo da vida perambulante dos caboclos da Ilha aproxima-se do modo como o "povo da rua" apresenta-se ao "povo da macumba" em terreiros da Baixada Fluminense, tal como descrito por Vânia Cardoso (2007; 2014). Em ambos os casos, nas histórias que os espíritos nos contam, nunca é dito exatamente onde eles viveram; nunca dizem exatamente quando suas vidas aconteceram; nunca dizem exatamente quem eles são. A indeterminação das idas e vindas da vida dos caboclos contrasta com os modos como sempre parecem saber dos passos de seus médiuns. Na Ilha do Massangano, o que se enfatiza da relação com os caboclos antes de ser uma qualidade de simetria, uma relação entre pares, é o fato de que sempre andam "mais nós", ao nosso lado e no "por aî".

Essa "narrativa acompanhada”, para usar um termo de Tim Ingold (2015) no livro Estar vivo: Ensaios sobre movimento, conhecimento e descriçâo, quando tomada junto aos caboclos é erigida por um critério de indeterminação. Ainda que muitos caboclos, como guias, indiquem caminhos a 
serem seguidos, o que meus interlocutores da Ilha apontam não é tanto o destino de sua jornada, mas o fato de que estão sempre "zanzando por aî", em um movimento de perambulação. $\mathrm{O}$ caboclo, para continuarmos com as imagens conceituais de Ingold, é menos um "passageiro" do que um "peregrino", já que estabelece uma relação com a terra a partir de movimentos indeterminados. Do lado da Ilha do Massangano, dizer que os caboclos estão sempre nos observando e vivem no "por aî" é dizer que eles habitam as passagens, e que eles próprios são também um caminho (“de luz"), um guia, para aqueles que com eles se relacionam. O que argumento é que as relaçôes com os caboclos, sua indeterminação perambulante, é atualizada na Ilha do Massangano como uma relação pensada como um caminho.

Se há um modo de parentesco dos caboclos com o povo da Ilha com o qual se anda mais, trata-se de um vínculo que se dá a partir da terra. São “conterrâneos" um dos outros - num sentido próximo ao que Dona Amélia atribuiu à sua relação com Dona Afra, uma velha senhora que há tempos viveu na Ilha, uma amiga que descreveu como de "caminho inteiro", e não "de meio de caminho" - uma das piores acusaçóes que se pode fazer a alguém da Ilha do Massangano, cuja compreensão de aliança e de amizade implica estar junto, em uma mesma terra, na composição de caminhos onde nunca se deve estar só, mas em boa companhia. Dona Amélia me disse que se não eram parentes, "era como se fossem, porque Dona Afra sempre foi mais nós”, que assim era porque eram conterrâneas, pois sempre caminharam juntas em uma mesma terra.

Caboclo, como me disse Corina, é tudo aquilo que se "pega" e "baixa" quando se "pisa no ouro" nas giras do chão de terra da Ilha. Pisar no ouro, como lembra Banaggia para o caso do Jarê (Banaggia, 2015, p. 273), refere-se ao costume antigo de que, uma vez "de caboclo", um médium pise sobre as brasas de uma fogueira sem ser por elas afetado. Na Ilha, tal costume persiste apenas no lastro da memória dos mais velhos. Hoje, o dizer "pisar no ouro ali" refere-se menos ao fogo e mais à terra: o movimento do "pisa-pisa” de pés descalços aponta para forças que passam pelo o chão. Essas práticas, Banaggia chamou, para o caso do Jarê, de "metafísica telúrica” e é 
precisamente este termo que quero retomar para nosso caso. Meu argumento é que, na Ilha do Massangano, tal telurismo se fundamenta a partir de uma composição com as águas que os rodeiam. A geometria que se desenha da composição terra-água parte de um modelo circular: a água não tem um lado apenas, ela circunda por todos os lados, está em todo lugar.

$\mathrm{Na}$ Ilha do Massangano, dizer que fulano "pega" caboclo, ou que o caboclo "baixa" em sicrano, é diferente de dizer que determinada pessoa é "possuída”, "possui", ou mesmo que "tem” caboclo. De certa forma, caboclo e caboqueira não coincidem, eles coexistem. $\mathrm{O}$ idioma da possessão é estranho aos dizeres de meus amigos quando falam da composição com seus caboclos. Ali, tais termos aparecem como categorias de acusação: só se é possuído pelo diabo, por uma "sombra", por "legiáo" - aqueles com quem não se quer nunca "andar mais" ou "ter parte". Ao revés, eles preferem o termo "pegar caboclo" ou "estar de caboclo", que enfatiza que a relação entre a "média" e seu caboclo se dá por um princípio de coexistência num mesmo espaço.

Ao discorrer sobre o enredo com os mortos que compóe a trajetória familiar de uma casa de Mesa Branca vizinha ao Gantois, Clara Flaksman (2016) apresenta uma versão distinta da que me foi apresentada na Ilha com os caboclos. Lá,

as pessoas [daquela família] que se submetem à feitura no candomblé [do Gantois] não têm, em suas cabeças, um espírito ao lado de seus orixás (ou santos): o espírito é uma parte de seus orixás e, consequentemente, uma parte delas (Flaksman, 2016, p. 143, grifos meus).

Dito isso, ela rejeita uma sugestão que lhe teria sido dada, a saber, a de que a relação com os orixás seria voltada para a forma de aliança. Para aquele contexto, o fato de que espíritos, orixás e gente náo sejam pensados como dispostos ao lado, mas como partes um do outro, levam-na a concluir que, para pensar as relaçóes entre partes como algo que é transmitido, lhe traz um maior rendimento analítico abordar a partir do modelo de participação, 
tal como elaborado por Márcio Goldman quando evocou a teoria da noção de pessoa no Candomblé.

Flaksman chama atenção para o fato de que Goldman inovou a teoria sobre a pessoa no candomblé ao olhar para a relação com os orixás a partir de uma via distinta das que até então eram vigentes. A autora argumenta que, tanto no caso do terreiro de nação Angola estudado por Goldman, quando no terreiro Ketu do Gantois, a pessoa é "formada ao longo de sua feitura, de acordo com as entidades que vão sendo incorporadas à sua cabeça” (2016, p. 15). A autora destaca que tal sistema de feitura, segundo Goldman, estaria ancorado menos num "sistema totêmico que estabelece relaçóes entre as diferenças existentes entre os seres humanos e as existentes entre os orixás", e mais num sistema próximo ao modelo do sacrifício, atualizado ali pelo fenômeno, justamente, da possessão: "por ser o único momento em que se dá a completude da pessoa, pois só na hora do transe ela é efetivamente possuída pela força, agora controlada, de seu orixá" (p. 15).

Por motivos semelhantes ao que me fora apresentado na Ilha do Massangano, Gabriel Banaggia (2015) argumenta que, para o Jarê, a relação caboclo-pessoa não passa tanto por um estatuto do ser (e da participação ou da possessão), mas por uma relação do ter - ou, no caso da Ilha, do "pegar".

[No Jarê] Não se diz recorrentemente que as pessoas 'são' das entidades, mas que elas as 'têm', que elas são capazes de recebê-las. As incorporaçóes no Jarê parecem menos evidenciar a existência contínua da entidade nos corpos do povo de santo - que seriam ativadas quase como um revés da pessoa durante as manifestaçóes - do que seus devires nos humanos, que funcionam justamente como aparelhos a captar determinadas frequências, sintonizar forças específicas (2015, p. 276).

$\mathrm{Na}$ Ilha do Massangano, tais relaçóes enfatizam uma relação de convivência, de copresença e de simultaneidade - se há participação, ela aparece na forma de uma composição à imagem da relação terra-água-correnteza de que dispóem. Isto é, as partes (terra e água) não se fundem em um ser só, elas são sempre disposiçóes transitórias de caminhos que andam num 
processo contínuo de junção e disjunção. Para falarmos da relação entre caboclo e caboqueira, já sabemos que na Ilha uma caboqueira não troca sangue com seu caboclo, ela o "coroa", andando "mais ele" atado com um broche ao corpo. A força dos "devires nos humanos" de que Banaggia fala no Jarê, se há na Ilha, é tomada no que o devir fala de jogos de alianças, uma aliança no entremundos de gente e de caboclos, por um desejo de se "andar mais", diante da composição de sua terra. O que argumento aqui é que, tal como apresentada pelos meus interlocutores da Ilha, a aliança se configura como a forma da relação com mundos que se póem lado a lado: ao mesmo tempo que é capaz de manter o traço diferenciador dos entes em relação, ela aponta para a indeterminação das disposiçóes destes caminhos.

Em outro artigo, Clara Flaksman (2018) pontua que o termo "enredo", segundo o povo do candomblé no terreiro do Gantois, onde fez campo, "É uma história"; "É a história da vida de uma pessoa"; "É uma coisa de família"; "É uma ligação que você tenha", e assim por diante (p. 127). O enredo, mais adiante ela completa, é uma "coisa bem do candomblé" (conforme lhe definiu sua interlocutora), uma relação, entre gente e espíritos, que se transmite pelo sangue. Nesse sentido, o "parentesco de santo" lhe foi apresentado como caminhando junto com o "parentesco de sangue"; um faz parte do outro. Assim, se "puxado para trás", o que o enredo apresenta é um caminho de "volta para casa": uma casa que, no limite, é a África, onde alguns de nossos ancestrais foram divinizados como orixás. Isto é, tendo a humanidade sido gerada naquele continente, todos nós descendemos dos orixás, tendo com eles um enredo. No entanto, a autora pontua, nem todo enredo aponta um caminho: isto é, ainda que todas as pessoas tenham orixá, nem todo orixá quer ser feito (p. 28). Caminho, no caso, é a vontade do orixá, que determina a feitura ou não da cabeça de um filho de santo, sua entrada ou não para a religião.

Se há na Ilha do Massangano, a forma-enredo, é mais próxima da noção tal como apresentada a Miriam Rabelo (2014) pelos adeptos do candomblé de casas não tradicionais de Salvador por ela estudadas, os quais, muitos deles, tiveram passagem pelos ritos de Mesa Branca. Ao traçar a trajetória 
da mãe de santo Dona Ditinha, Rabelo escreve que sua "volta para casa” se constituiu a partir de um movimento errático de perambulação, em um entrecruzamento de caminhos compostos por vínculos de sangue e de santo, mas também de vicinalidade.

Não é o percurso do espiritismo ao candomblé - ou mesmo de um terreiro a outro de candomblé - que define a vida de Dona Ditinha, mas o movimento constante e incerto pelo qual caminha - ora se aproximando, ora se afastando do candomblé - movimento que a conduz para longe e que, ao final, a reconduz à sua própria casa, onde é feita segundo a vontade de sua Oxum. [...] Podemos identificar três dimensôes desse movimento de retorno: primeiro é o retorno à casa como lugar de procedência, ponto de onde se partiu; segundo é o retorno ao passado, retomado como obrigação (Ditinha herda e retoma a obrigação de sua mãe); e terceiro é o retorno àquilo que sempre foi (Ditinha assume os vínculos que desde sempre a ligaram a Oxum) (Rabelo, 2014, p. 76-77).

O destaque do trecho justifica-se pelas semelhanças da trajetória de Dona Ditinha com a de Peba. Ainda que não seja um termo corrente na Ilha, poder-se-ia dizer que o enredo que Peba tem com seus caboclos vem "de nascença", tendo-o também descoberto em um itinerário de volta para casa. Sua casa, no caso, era a sua vizinhança. Isso porque, ainda que sua mãe muito tenha caminhado para índios, caboclos e pais de santos nos arredores da Ilha, o "corpo todo feridento" dos quinze anos de Peba apenas foi achar cura do lado de casa: na casa de caboclos de Maria de Lauro, caboqueira fina que posteriormente lhe coroou com Vencedor, o guia com quem ela "nasceu mais". Assim, não é que Peba tenha herdado a relação de seu pai com determinados santos ou caboclos - estes, ela já tinha "de nascença” -, o que ela herdou foi a obrigação que seu pai tinha com eles. De modo semelhante ao que me foi apresentado na Ilha, Rabelo reporta que a ancestralidade em que o discurso de seus interlocutores se apoia ao falarem de seus caminhos junto às entidades, se existe, só faz sentido quando se refere a "uma obrigação herdada" (p. 77). 
Peba não cansa de repetir que a obrigação com Cosme e Damião não é sua, mas de seu pai, de quem a herdou. Que o pai lhe veio "em vida” - isto é, já depois de morto, mas caminhando, "assim mesmo, que nem nós, com os pés assim, alteando o chão", para lhe dizer que nunca deixasse de dar a "festa dos meninos”. É a vontade de seu pai, junto à vontade dos caboclos, o que a "obriga" a realizar tais festas. Nanosa, uma outra caboqueira de lá, disse-me que "não era obrigada”, e que se "caminhava mais" os espíritos, era por fé e gosto de ajudar quem precisa - sejam almas, caboclos ou gente como ela. Obrigação mesmo só com as velhas, que lhe ensinaram que é dando que se recebe, e que o que a gente faz nesta vida leva para a outra. O que Nanosa me dizia é que ela tem gosto pela obrigação. Em certo sentido, ela escolhia ser obrigada - ao modo da vingança dialética que Eduardo Viveiros de Castro (2009) apontou, em artigo dedicado a inventariar as teorias sobre parentesco, analisadas a partir do eixo escolha/obrigação, como sendo próprias às descriçóes de sociedades baseadas na dádiva (em oposição à escolha forçada, compulsória, das sociedades baseadas na mercadoria). No entanto, a palavra "gosto" aqui não coincide com a palavra "escolha", tal como colocada pelo autor. Nanosa náo diz que escolhe caminhar na companhia dos espíritos. Ou pelo menos, se há escolha, não é apenas dela: o gosto pela obrigação implica a realização de um conjunto de escolhas que é também das avós, das mães, do tempo, dos caboclos, das almas, de Deus. Se há enredo na Ilha do Massangano, ele é pensado em termos de uma obrigação.

O gosto e obrigação por com quem se "anda mais" passa por uma relação com a terra. O caminho de volta para casa é tecido na perambulação, que no giro de Peba apontou para sua vizinhança. Algo próximo ao que Rabelo escreveu ao seguir a trajetória dos filhos de santo das casas de Salvador, traçadas "através de redes intrincadas de trocas, alianças e disputas envolvendo não só os sujeitos, seus familiares e vizinhos e as lideranças religiosas, mas também as próprias entidades; não só a casa e o terreiro, mas o bairro e a rua" (2014, p. 65, grifo meu). Se há escolha, quando posta no campo da obrigação, ela não pertence a uma pessoa só - já que nunca, a rigor, se está sozinho. A profusão de agentes que compõem o "gosto pela obrigação" 
na Ilha indica a necessidade de saber com quem se aliar. Uma aliança que, com os caboclos, é pensada ao modo de uma corrente.

\section{ALIANÇA COM A TERRA: CABOCLO COMO PERMANÊNCIA}

A "festa das águas", empreendida por Peba como o cumprimento de uma obrigaçáo que era de seu pai, é uma versáo mais acanhada da festa da Marujada de Berto Barrinha. O modo intermitente como Peba abre sua casa de caboclos para giras acompanha o recuo da força das águas da correnteza do rio. No entanto, Peba persiste na empreitada das festas, diante não apenas da obrigaçấo com o pai, mas também porque sabe que os caboclos continuam "por aí, andando", e que, por isso, no "desincerto", podem fazer sua vida "andar para trás". Foi assim que, em 2015, mesmo diante da pouca quantidade de água do rio, onde no porto em frente à sua casa só se via pedras, Peba promoveu alguns desvios de rota, de modo que a festa não fosse contornada.

Em vez de sairmos de seu porto, como de costume, o barco no qual saímos sobre a correnteza das águas nos aguardava no porto de seu vizinho, onde a saída era melhor. Conduzidos por "cantigas das águas", seguimos em fila desde a casa de Peba, segurando nossas velas. À frente, Silvano levava a oferenda na forma de um barquinho branco com uma boneca vestida de sereia, flores brancas e azuis, além de sabonetes e perfumes. O barquinho foi confeccionado por Gildo, irmáo de Peba, que nos aguardava no porto, em uma embarcação onde trabalha como piloto atravessando banhistas para o balneário da praia de uma ilha vizinha. Uma vez no porto, caboqueiras mais experientes convenciam os mais resistentes a entrarem no barco, garantindo-lhes que não os deixaria se jogarem com seus caboclos nas águas. Desde as festas das Marujadas, sabem que a vontade de todo caboclo é essa, e que cabe à fineza do caboqueiro equilibrar-se sobre os paquetes. Uma vez no barco e o barco sobre o rio, vieram os caboclos de uma só vez, um após o outro, e concomitantemente. As caboqueiras vigiavam-se. Vencedor, que 
comandava o passeio, era contido por outra "média", que dosava sobre a cabeça de Peba respingos da água do rio. De outro barco menor nos seguia Vado, irmão mais novo de Peba. Ele cumpria uma função importante: diante da baixa vazão do rio, ocupava-se em recolher o "barquinho das oferendas" para levá-lo mais adiante até um ponto do rio de maior correnteza, onde a embarcação de seu irmão Gildo "não tinha passagem". No momento em que Vado alcançou um ponto de correnteza e deixou o barquinho ser levado por ela, soltaram-se fogos de artifício e todos os que permaneceram no barco maior jogaram suas velas nas águas do rio.

Fotografia 2: O barco menor e o maior (Márcia Nóbrega, 2016)

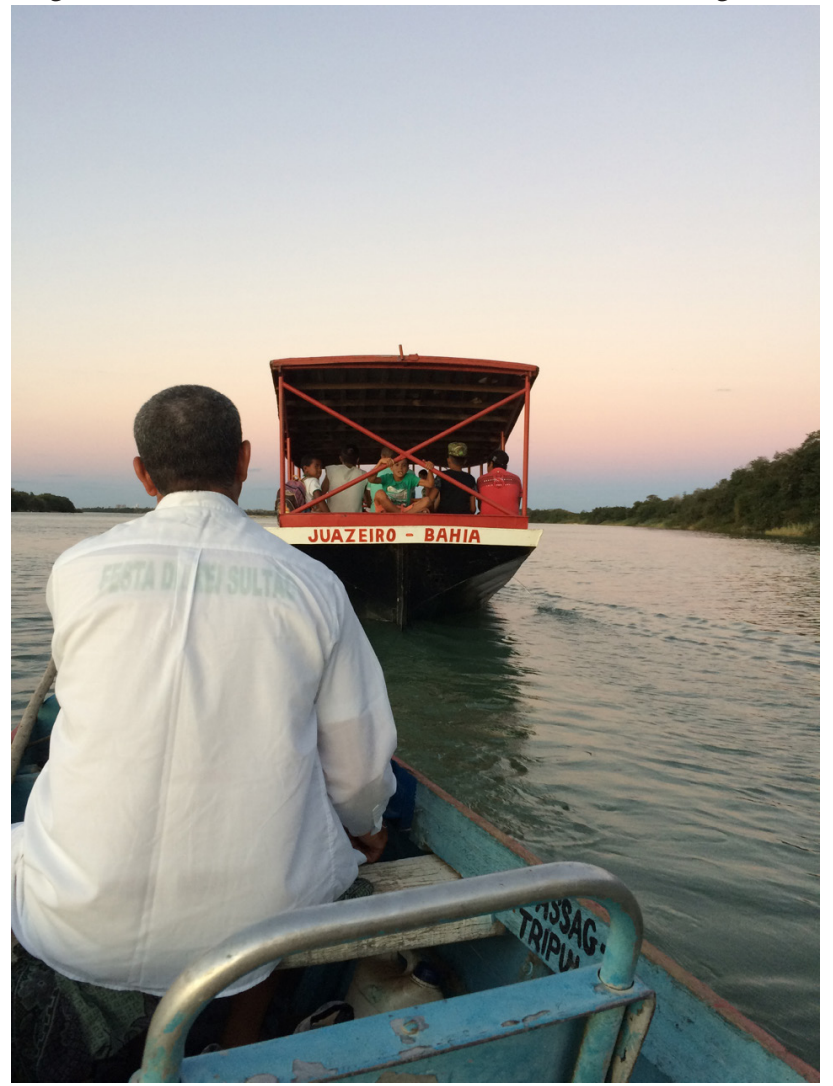

Debates do NER, Porto Alegre, ano 20, N. 38, P. I8I-2 Io, Ago./DeZ. 2020 
Meses depois, já em 2016, no dia dois de fevereiro, quando na Ilha se celebra o dia de Nossa Senhora das Candeias, foi a vez de Peba conduzir a festa da Caboclinha Coroada do Rio, que é um de seus guias, assim como Vencedor e Gritador. De seus três guias, a festa da Caboquinha Coroada do Rio é a única que é feita por gosto: não como uma obrigação herdada do pai, tampouco porque a cabocla pediu, como às vezes costuma ser. Ela me descreveu a festa como "simples", quando se oferecem sobre as águas uma coroa de flores e, sobre as pedras, velas acesas. Peba lamentava não ter tido tempo de achar outras flores melhores e conformou-se com algumas de plástico e com os lírios que colhera em seu terreiro. Também não havia mais cabaças disponíveis, como antes, onde costumava depositar as oferendas. O jeito foi improvisá-las em um prato de plástico. Mas tudo sairia bem, acreditava. Seus caboclos demandam, mas costumam ser compreensivos.

Fotografia 3: A corrente e a correnteza: Vado recolhe as oferendas (Márcia Nóbrega, 2017)

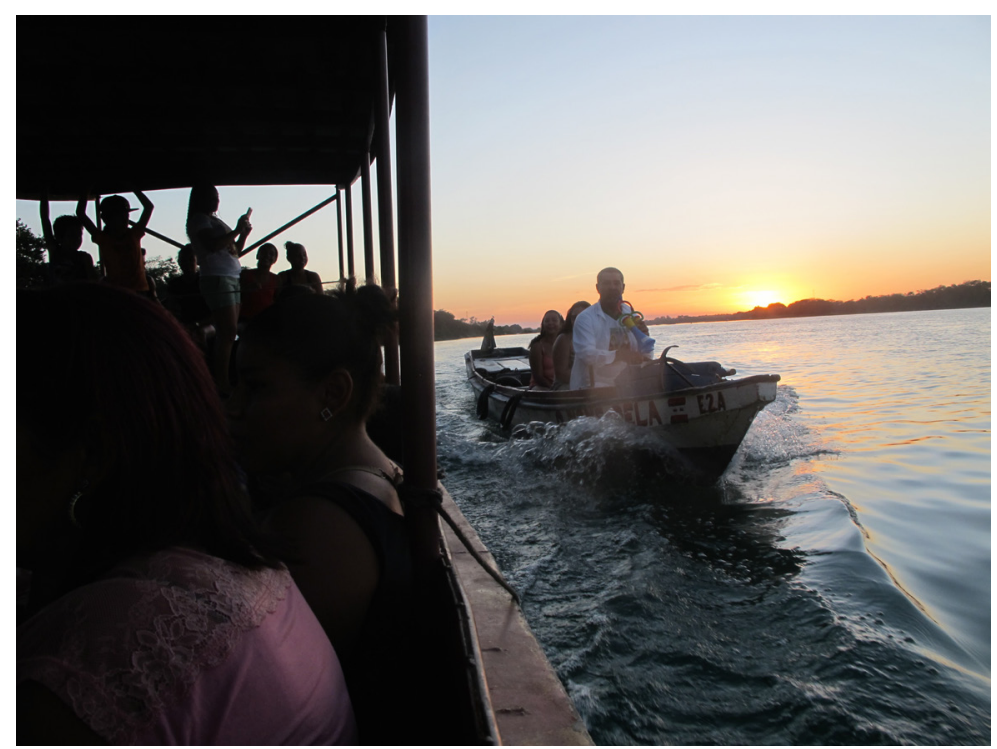

Debates do NER, Porto Alegre, ano 20, N. 38, P. I 8 I-2 io, Ago./Dez. 2020 
Vado chegou junto ao anunciar dos fogos de artifício. Ele e a irmã comentaram sobre as últimas chuvas de janeiro, que haviam comido o barro de uma das paredes da casa de caboclos de Peba, que a restaurou improvisando um tapume com lona preta para a ocasiáo da festa. Vado, em tom de piada, disse que a dona da casa não era lá muito empenhada e que o que lhe impressionava era a casa não ter caído por inteiro. Peba sorriu, mas adiantou que, "se Deus quiser", ela mesma se encarregaria de derrubar as outras paredes para reconstruí-las em bloco - o que de fato fez no ano seguinte. Naquele momento, sua preocupação não era com a parede e sim com o Padre Cícero, cuja estatueta tivera a cabeça decepada do tronco ao cair junto com a parede durante as chuvas. Peba nos explicou que, assim como remendara a parede com lona, também havia restaurado com cola a imagem rompida do santo padrinho. No entanto, algo ainda a incomodava naquele remendo. Tinha a intençáo de comprar uma estatueta nova na romaria a Juazeiro do Norte que estava por vir, mas fora desmotivada pelo irmão: "Está bom do jeito que está, é só passar tinta preta no risco do gesso, eles aceitam".

Debates do NER, Porto Alegre, ANo 20, N. 38, P. I8 I-2 Io, AGo./DeZ. 2020 
Fotografia 4 - O fundo e a força: As oferendas ganham a correnteza (Márcia Nóbrega, 2017)

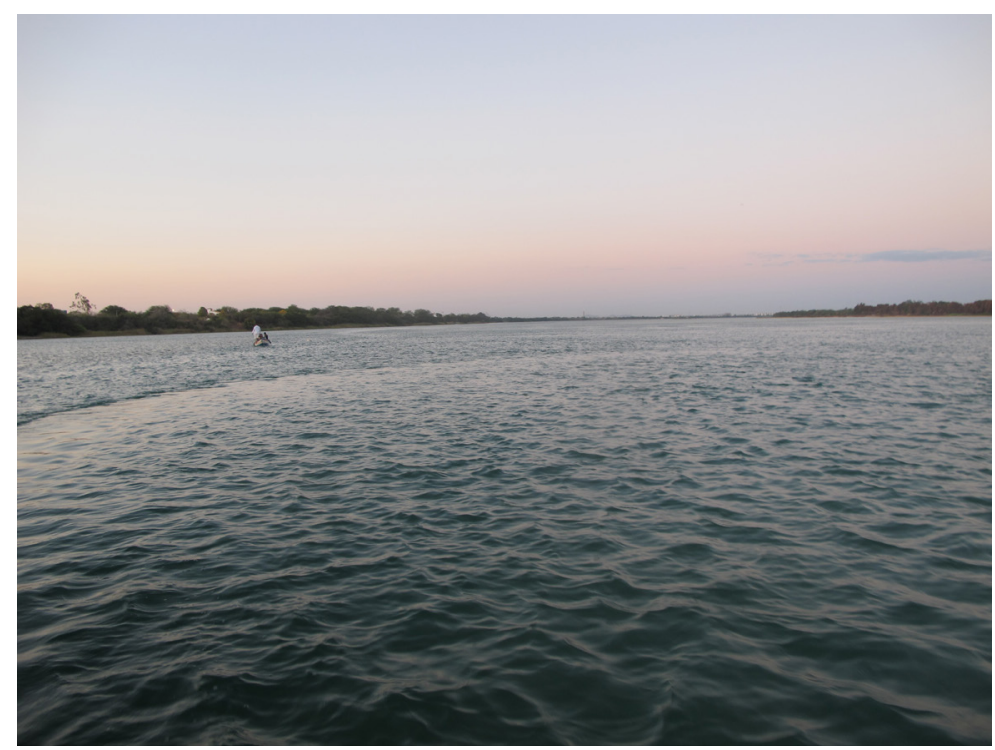

Com sua voz doce, a Caboquinha Coroada do Rio veio agradecer e abençoar a todos, dando início a festa para logo em seguida ir embora. Como de costume, quem comandou a festa foi Vencedor, que puxou as primeiras cantigas. Com toda a elegância com que costuma conduzir as giras, Vencedor reclamou da pouca vontade com que entoavam as cantigas: "Não tinham comido nada, ou era só peixe?", brincou. Com uma cruz em mãos, pediu que nos reuníssemos no centro do salão e jogou água sobre nós. Antes de partir, aconselhou que brincassem mais, que fizessem mais giras, para que fosse possível puxar pela memória as cantigas que outrora, como seus caboclos, foram-lhes tão familiares. As "médias" resignavam-se de que "era assim mesmo", mas, "se Deus quisesse", tudo seria diferente: a casa de bloco, uma nova imagem de Padre Cícero, as giras e as festas, como no tempo da Marujada. Por ora, o jeito era levar a vida adiante "do jeito que desse", nem que fosse como um remendo.

Debates do NER, Porto Alegre, ano 20, N. 38, P. I 8 I-2 Io, Ago./Dez. 2020 
A relação com os caboclos é algo que sempre está em negociação. Um tipo de experimentação: a ver se "dá bem", se eles, os caboclos, aceitam. Nas festas de caboclo de Peba, não se vê uma rigidez ritual estabelecida. $\mathrm{O}$ modelo a ser seguido - o de "como pai fazia" - admite frequentes variaçóes. Tudo se passa como se... nesse ano não houve cumbuca de cabaça, mas poderia ter tido; houve lírios colhidos, mas poderia não ter tido. Em suma, trata-se sempre de algo que deveria ter sido feito, mas, se não puder ter sido, tudo bem. À semelhante pragmática, agora sob os efeitos de encontros no Candomblé - "o que funciona", "o que é bom para usar", "o que o santo aceita" -, o Xicarangoma (que é como no Candomblé de nação Angola se designa uma função específica de Ogã), Esmeraldo Santana (1984) chamou, no Encontro de Naçóes-de-Candomblé, em Salvador, de "Teoria da Milonga":

Há pouco tempo houve uma polêmica por causa da palavra milonga. Mas milonga é mistura. Foi assim que eles fizeram. Misturaram, porque nas senzalas tinha todas as 'naçóes' e, quando era possível eles faziam qualquer coisa das obrigaçóes deles, então cada um pegava um pedaço, fazia uma colcha de retalhos, um cozinhava isso, outro cortava aquilo, outro pegava. A mesma coisa fez-se no cântico. Um, 'eu sei tal cantiga', outro, 'eu sei tal', e todos cantavam, e então o 'santo' aceitava, e não ficou somente uma 'naçâo' pra fazer aquele tipo de obrigação. Era a mistura, como já disse, a milonga (Santana, 1984, p. 36).

Neste sentido, uma mistura é um experimento na pragmática das alianças. No caso, Esmeraldo Santana falava sobre os modos como se deu a formação da nação Angola, da qual faz parte. Na possibilidade de habitar um mundo novo, sua nação se fez, como uma milonga, à imagem de uma colcha de retalhos: uma costura tecida em encontros forçados nas senzalas, onde foram reunidas artificialmente tecnologias de distintas naçóes - "cambinda, moçambique, munjola, quicongo. Tudo isso é angola” (p. 36). É a partir de uma negociação com as entidades (a ver se "dá bem" e se o santo ou o caboclo "aceita") que costuras e remendos possibilitam a coexistência entre distintos entes em uma terra, diante mesmo de sua precariedade. 
No entanto, como sabem meus interlocutores da Ilha, há sempre a possibilidade de os caboclos não aceitarem. Mais cedo, antes da gira, quando na noite escura foram depositar a oferenda para a Caboclinha Coroada sobre as águas do rio, observaram, com ajuda da iluminação das velas, que o rio parado, porque sem correnteza, não fora capaz de empurrar sozinho o presente para a cabocla da corrente das águas. No entanto, não interpretaram a inércia com que a obrigação das oferendas caminhava como uma recusa do presente por parte dos peixes ou da cabocla. Os tempos são outros - eles, os caboclos, sabiam. Por isso Peba insistia: nem que tivesse que ir mais longe, não deixaria de fazer sua obrigação com eles. Sabem que o desacordo entre gente e caboclos, quando há, só se sabe a posteriori, diante dos efeitos: panelas caem, adoece-se, tudo na vida dá "desincerto".

$\mathrm{Na}$ festa da corrente das águas, diante da pouca quantidade de água, Peba persistiu em seus remendos: aportou a barca maior de seu irmáo, Gildo, mais longe, no porto onde havia saída; e, com o barco menor do irmão Vado, costurou artificialmente as correntezas, de modo que tornasse possível reconectar as correntes. Isto é, enquanto Gildo levou as "médias" da festa até onde o rio "tinha fundo", Vado levou a oferenda aos caboclos até onde o rio "tinha corrente". Peba, a seu modo e "do jeito que dá", remendou fundo e forma para tornar possível a obrigação de seu pai. Peba, mesmo que não alcance produzir água ou fazer recuar a terra, mobilizou barcos, acendeu velas, empurrou oferendas para pontos do rio onde ainda há fundo e força. Caboclos, gente, velas, lírios, flores de plástico, lonas, barcos menores, maiores, pedras, correntes e correnteza; entes de mundos distintos e materiais heterogêneos são unidos para fazer a vida perseverar. Remendados como uma colcha de retalhos, à imagem do ciborgue de Donna Haraway que inspirou Strathern (2004 [1991]) na elaboração de suas Partial Connections, na esperança de que suas partes lesadas fossem compatíveis, que "dessem bem" e que os santos e caboclos "aceitassem". É nesse sentido que meus amigos da Ilha especulam suas combinaçóes engenhosas, que, por sua vez, implicam riscos que são sempre calculados, mas nunca controlados. 
A instabilidade e a provisoriedade de estados de mundo são os modos como aprenderam a viver, e é a partir deles que mobilizam os veículos com que tecem alianças em terra. Há sempre, eles sabem bem, a possibilidade de caboclos-almas-santos não aceitarem, do "desincerto", da vida andar para trás, de um mundo virar no outro - ou mesmo de acabar. A cosmopolítica acionada na composição de mundos, na terra da Ilha do Massangano, aproxima-se, nesse sentido, do que foi sugerido por Isabelle Stengers (2018) no texto $A$ proposição Cosmopolitica. Trata-se de uma aliança, que segue o paradigma que a autora chama de "eto-ecológico", tecida entre o oikos (espaço/ambiente) e o ethos (comportamento) dos seres que o habitam, cujos movimentos entre um e outro produzem efeitos sempre indeterminados. A 'ecologia política' coloca o sentido do termo 'político' ao lado do 'cosmopolítico', uma vez que fala de uma arena de decisóes onde são consideradas agências diversas que compóem mundos vividos. Agências estas, Stengers sugere, que não podem ser negociadas pressupondo a ideia de um parlamento onde todos seriam iguais, neutros e cegos à diferença. No caso dos habitantes da Ilha, eles tecem negociaçôes (a ver se dá bem e se os caboclos, almas, santos aceitam) diante e na presença dessas entidades, as quais sofrerão as consequências, desde seus próprios mundos, dos desajustes passados em terra. Para eles, o cosmos, que é construído por entidades múltiplas e diversas, não é feito de águas calmas, de paz transcendente, mas de encontros, muitas vezes turbulentos, que concorrem para fins desconhecidos.

"Deus não quer da gente o impossível" é o dizer que acionam quando falam de alguma negociação que sabem ser aquém da que os caboclos desejariam. Sabem, no entanto, que o possivel, justamente, é o domínio de atuação dos caboclos. Se "Deus não quer da gente o impossível”, os caboclos cobram o que sabem ser possível. Diante disso, Peba insiste em produzir corrente nas fracas correntezas do rio. Se não se sabe bem onde os caboclos vivem e o que fazem, não há dúvidas de que em algum lugar eles existem, "por aî", "andando" - mesmo que sigam para terras distantes. O sertão, para o povo da Ilha, é uma categoria que a tudo alcança: refere-se às terras de meio de rio, às de beira de rio, porém firmes, às de caatinga. Eles sempre 
estiveram no sertão porque o sertão, como escreveu João Guimarães Rosa, está em toda parte. Um sertão de águas, contudo. O signo terra, ali, compóe em força com as águas, substância amiga dos caboclos. Isto é, o telurismo dos caboclos na Ilha indica o gosto pela terra, mas é para a correnteza das águas que apontam quando falam da força que eles têm: é o agenciamento corrente-correnteza que faz passar a vida, carregando-a mais adiante e tornando-a possível. Enquanto houver terra e houver rio, sempre haverá um sertão para onde correr, seja em barcos maiores ou menores, conforme sejam as profundezas e forças das correntezas das águas. Se "Caboclo é tudo" é, sobretudo, porque ele permite todo tipo de aliança com a terra: é tudo aquilo que "baixa”, "pega", "vem" e "desce” nas giras de terra em meio às águas da Ilha do Massangano. Caboclo, assim, fala de permanência, da insistência na vida, da capacidade de conjuntar para conjurar fins de mundo.

\section{REFERÊNCIAS}

BANAGGIA, Gabriel. As forças do Jaré: religiāo de matriz africana da Chapada Diamantina. Rio de Janeiro: Garamond. 2015.

CARDOSO, Vânia. Narrar o mundo: estórias do "povo da rua” e a narração do imprevisível. Mana 13(2): 317-345. 2007

CARDOSO, Vânia. Spirits and Stories in the Crossroads. In: BLANES, Ruy; ESPÍRITO SANTO, Diana (orgs.). Introduction: On the Agency of Intangibles. The social life of spirits. Chicago: The University of Chicago Press. 2014.

FERRAZ, Socorro; FERRAZ BARBOSA, Bartira. Sertão: Fronteira do Medo. Recife: Editora UFPE. 2015.

FLAKSMAN, Clara. Relaçóes e narrativas: o enredo no candomblé da Bahia. Religião e Sociedade, Rio de Janeiro, 36(1): 13-33. 2018.

FLAKSMAN, Clara. "De sangue" e "de santo": o parentesco no candomblé. Mana 24(3): 124-150. 2016. 
GUIMARÃES ROSA, João. "A terceira margem do rio". In: Fiç̧ão completa: volume II. Rio de Janeiro: Nova Aguilar, p. 409-413. 1994.

INGOLD, Tim. Estar Vivo: Ensaios sobre movimento, conhecimento e descriçäo. Petrópolis, RJ: Vozes. 2015.

MARQUES, Ana Cláudia. Founders, ancestors, and enemies: memory, family, time, and space in the Pernambuco sertão. Journal of the Royal Anthropological Institute (N.S.) 19, 716-733. 2013.

MARQUES, Juracy; NOVAIS, Joaquim. Candomblé e Umbanda no sertão: cartografia social dos terreiros de Petrolina-PE e Juazeiro-BA. Paulo Afonso/ BA: Editora da SABEH. 2015.

MARTINS COSTA, Ana Luiza Borralho. Uma retirada Insólita. Coleçáo Território, Ambiente e Conflitos Sociais. No 4. IPPUR/UFRJ. 2013.

NEVES, Zanoni. Navegantes da Integração: os remeiros do Rio São Francisco. Belo Horizonte: Editora UFMG. 1998.

RABELO, Miriam. Enredos, feituras e modos de cuidado: dimensóes da vida e da convivência no candomblé. Salvador: EDUFBA. 2014.

SANTANA, Esmeraldo Emérito. Nação Angola. Encontro de Nações-de-Candomblé. Salvador: Centro de Estudos Afro-Orientais da UFBA/Ianamál Centro Editorial e Didático UFBA. 1984.

SANTOS, Jocélio Teles dos. O dono da Terra: o caboclo nos candomblés da Bahia. Salvador: Sarah Letras. 1995.

SERRA, Ordep. Na trilha das crianças: os erês num Terreiro angola. Dissertação de Mestrado. PPGAS- UnB. Brasília. 1978.

STENGERS, Isabelle. No tempo das catástrofes - resistir à barbárie que se aproxima. São Paulo: Cosac Naify. 2015.

STENGERS, Isabelle. A proposição cosmopolítica. Revista do Instituto de Estudos Brasileiros, Brasil, n. 69, p. 442-464, abr. 2018. 
STRATHERN, Marilyn. Partial Connections. Updated Edition. Oxford: Altamira Press. 2004 [1991].

VIVEIROS DE CASTRO, Eduardo. The gift and the given: three nano-essays on kinship and magic, kinship and beyond. In: BAMFORD, Sandra C.; LEADCH , James (Orgs). Kinship and beyond: the genealogical model reconsidered. New York, Oxford: Berghann Books, pp. 237-268. 2009.

Recebido em: 07/08/2020

Aprovado em: 02/10/2020 